\title{
Diseases of flounder Platichthys flesus in Dutch coastal and estuarine waters, with particular reference to environmental stress factors. I. Epizootiology of gross lesions
}

\author{
A. D. Vethaak*, J. G. Jol \\ Ministry of Transport, Public Works and Water Management, Directorate-General for Public Works and Water Management, \\ National Institute for Coastal and Marine Management/RIKZ, Ecotoxicology Section, PO Box 8039, 4330 EA Middelburg, \\ The Netherlands
}

\begin{abstract}
In order to investigate potential links between marine pollution and fish diseases, an epizootiological study was conducted in The Netherlands during 1983-89. This study concentrated on grossly identifiable diseases of flounder Platichthys flesus. Flounder were found to be affected by the viral skin disease lymphocystis and by skin ulcers probably of bacterial origin. Overall prevalences of these 2 diseases in fish $\geq 2$ yr old were $14.3 \%$ and $2.8 \%$ respectively. Also notable was the presence of neoplastic nodules in the livers of $1.0 \%$ of the population, prevalences rising steeply with age and locally attaining values of up to $30 \%$ in $6+$ yr old fish. Most of the samples were collected in September when flounder are resident in inshore feeding arcas. Using data from 9 sites, spatial and temporal (year-to-year) variation in disease occurrence was analysed statistically using log-linear models which incorporated possible effects of length, age and sex. Year-toyear variation showed little correspondence among the 3 diseases, but their spatral distributions showed striking similarities. Lymphocystis and skin ulcers were associated in individual fish. The observed variation in disease prevalence showed no significant correlation with condition factor of the fish or with concentrations of contaminants in sediments or tissues. However, disease prevalences at different sites showed a strong positive correlation with fishing activity (possibly indicating an effect of damage by fishing gear) and appeared also to be positively related to salinity. When only strictly marine sites were considered, a relationship with pollution could not be ruled out. Additional data collected in February-April at offshore sites indicated that disease prevalences were generally higher at this time of the year, which corresponds to the spawning period of the populations studied. This trend was particularly pronounced for liver neoplasms, and might be partly related to a low condition factor resulting from spawning activities. In view of the different aetiologies of the 3 diseases, the similarities in spatial patterns indicate the existence of 1 general underlying mechanism of disease causation, perhaps acting through immunosuppressive effects. However, age-related migration appeared to explain some aspects of the spatial pattern of liver neoplasms, whereas it was less important in the case of epidermal diseases, which develop more rapidly. On the basis of the findings of this study, the possible contribution of pollution to disease prevalence cannot be adequately assessed due to the interfering effects of other factors (salinity, fishing activity, migration and spawning). Disease causation appears to be complex, and it may be that effects of pollution interact with those of other factors to produce observed spatial patterns.
\end{abstract}

KEY WORDS: Flatfish - Fish health - Marine pollution - Environmental stress · Biological effect monitoring - Liver neoplasms · Epizootiology

\section{INTRODUCTION}

With growing concern about marine pollution, interest in the potential of fish diseases for monitoring

•E-mail:vethaak@rikz.rws.minvenw.nl environmental quality has increased considerably in recent years (Vethaak \& ap Rheinallt 1992). In the North Sea area, most studies have focused on diseases of dab Limanda limanda (e.g. Bucke et al. 1984, Dethlefsen et al. 1987, Vethaak \& van der Meer 1991, Vethaak et al. 1992). At present there is no general 
consensus about the importance of pollution as a causative factor for disease in this area, although some studies appear to provide convincing evidence for a positive relationship (see recent review by Vethaak \& ap Rheinallt 1992). The situation in the North Sea contrasts with that prevailing on the other side of the Atlantic, where an impressive body of evidence has been assembled for a link between liver abnormalities and pollution (particularly polycyclic aromatic hydrocarbons, PAHs; e.g. Malins et al. 1988, Moore et al. 1989, Vogelbein et al. 1990, Myers et al. 1991, 1994).

The present study concentrated on European flounder Platichthys flesus, which are restricted to coastal waters where pollution loads are highest. Earlier studies of this species in the North Sea and the Irish Sea were unable to produce evidence for a direct effect of pollution on disease prevalences (Perkins et al. 1972, Shelton \& Wilson 1973, Newell et al. 1979, McArdle et al. 1982, Bucke et al. 1983a, b, Reiersen \& Fugelli 1984). However, these negative findings may be partly attributable to methodological shortcomings (Vethaak \& ap Rheinallt 1992).

More recently, a small number of more thorough studies have been published. Extensive studies of diseases of flounder in the Elbe estuary and the German Wadden Sea (Möller \& Anders 1986, Möller 1990) showed that high disease prevalences were associated with fluctuating salinities and hence reduced food supplies. Pollution was not considered to be a major factor causing disease.

A survey of flounder diseases in the Dutch Wadden Sea in 1988 (Vethaak 1992) revealed particularly high prevalences of skin ulcers (20 to $50 \%$ ) at certain localities, where fresh water is irregularly discharged. In the freshwater bodies behind the sluices, prevalences were very low. This suggested that bacterial infection, osmotic stress, and anaerobic sediments, as well as perhaps crowding and nutritional deficiencies, might be involved in disease causation (Vethaak 1992).

In contrast, comprehensive studies of liver pathology in flounder from the Elbe provide convincing evidence for a causal relationship between liver disease and pollution, in particular by chlorinated hydrocarbons (Peters et al. 1987. Köhler 1989). Major liver damage was confined almost exclusively to fish from the polluted river Experimental studies showed that regeneration of the liver occurred when the fish were kept in clean water and fed a contaminant-free diet (Köhler 1989).

\section{Biology of the flounder}

The flounder is a common species on soft substrata in coastal waters, estuaries and large freshwater bodies in The Netherlands. There, it may be exposed to high levels of pollution. It is a euryhaline species: flounder spawn in offshore marine waters but both the nurseries and the feeding grounds of the adults are concentrated in or near estuaries (De Veen 1971). The majority of juveniles occur in brackish and fresh water (Rijnsdorp \& Vethaak 1989). It appears that during the first years after settlement there is a downstream migration and 4 yr old and older fish seldom occur above the estuary mouth (author's unpubl. obs.).

Flounder from German-Dutch inshore waters, estuaries and fresh water migrate offshore in winter to spawn (Redeke 1908, Ehrenbaum 1908, De Veen 1971). There was also evidence for strong homing behaviour from one year to the next with respect to the ieeding grounds (De Veen $19 \overline{9} \not$ ).

Because of their migratory behaviour, only during summer can flounder captured at a given location be assumed to have been feeding there for any length of time. For this reason, September was selected as the month for sampling in this study, in the expectation that the disease status of flounder would reflect locai conditions over the previous 3 to $4 \mathrm{mo}$. In view of their homing behaviour, cumulative effects of local conditions over several years may be expected in the case of older individuals.

\section{Scope of the present study}

The results of a preliminary inventory (Vethaak 1985) indicated that the flounder was the most suitable flatfish species for monitoring pollution in near-shore and estuarine waters. Three flounder diseases were considered potentially useful for study: lymphocystis (viral), skin ulcers (associated with bacteria), and liver nodules (aetiology unresolved). Fin rot, although frequent, was excluded because of diagnostic problems related to mechanical damage (Vethaak 1992).

The study lasted from 1983 to 1989. The principal objective was to map the occurrence of grossly identifiable diseases in flounder inhabiting various areas subject to different degrees of pollution. Interim reports have been published previously (Vethaak 1987. 1991, Marquenie \& Vethaak 1989). In this paper the epizootiology of the 3 diseases is described in detail. Associations between certain potential risk factors (fish condition, salinity, fishery impact, pollutant concentrations) and spatial and temporal variation of disease occurrence are examined in an attempt to evaluate the impact of pollution.

The present study focused on effects of chemical pollution. These were estimated by selecting as indicators several important organic contaminants and heavy metals, which showed pronounced spatial vari- 
ability and were considered representative of the total pollution load (Akkerman et al. 1992).

Although the study concentrated on the inshore feeding phase of the species' annual cycle, some data are presented on disease prevalences during the spawning period in offshore waters.

\section{MATERIALS AND METHODS}

Sampling sites. Sampling areas were chosen on the basis of chemical data available through various environmental monitoring programmes carried out by the Directorate-General for Public Works and Water Management (RWS) of the Dutch Ministry of Transport, Public Works and Water Management, as well as on the basis of the occurrence of the target species. The pollution status of Dutch coastal and estuarine waters is well documented $(\mathrm{Ak}$ kerman et al. 1992, North Sea Task Force 1993). The main anthropogenic sources of contaminants in these waters are the rivers Rhine and Meuse, the river Scheldt (the Western Scheldt estuary) and the North Sea Canal (Fig. 1, Table 1).

Sampling of the feeding population in late summer (September): From 1983 until 1987 surveys were limited to 3 sites, 2 in coastal waters (Sites 5 and 6 ) influenced by the outflow of the river Rhine, and

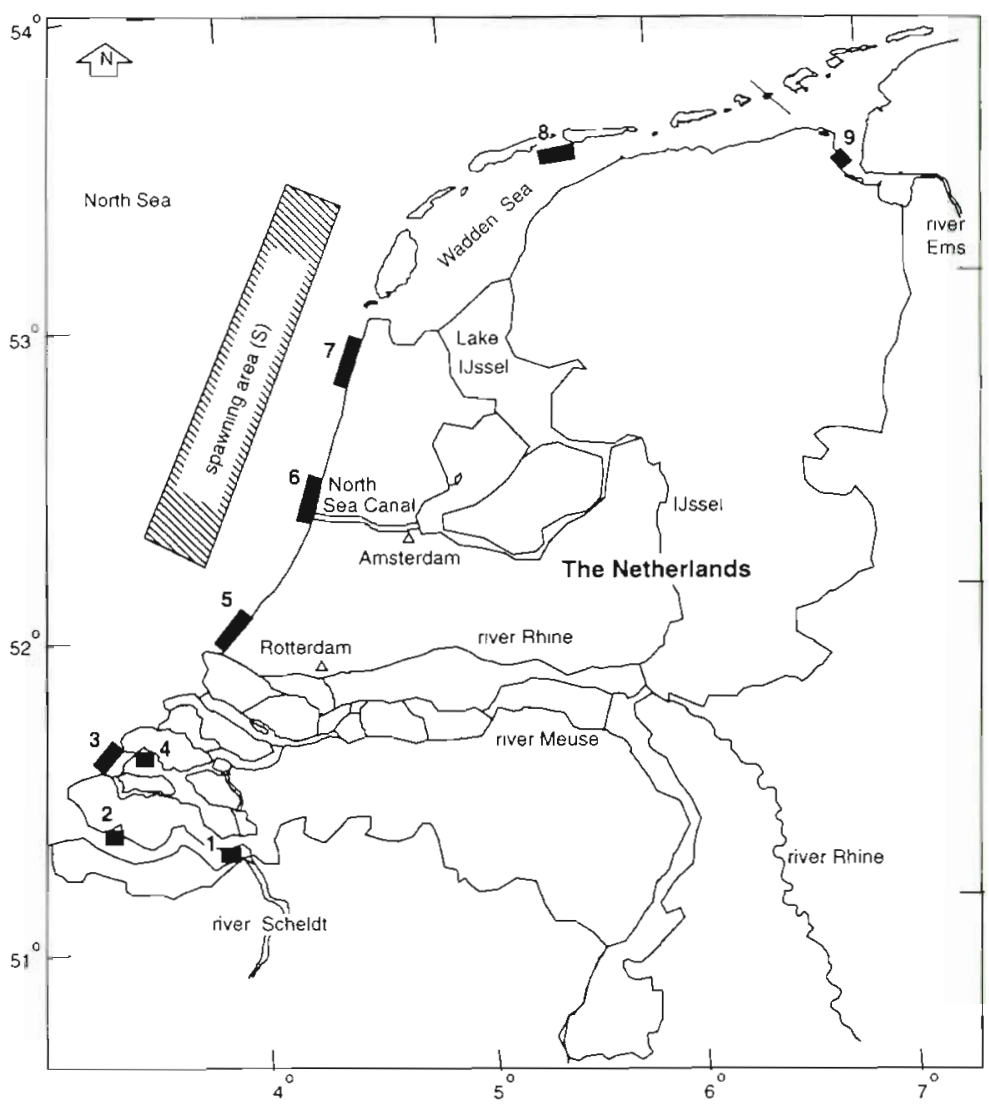

Fig. 1. Geographic position of the study sites sampled in September (Sites 1-9) and those sampled in February-April (Area S)

a reference site in the Eastern Scheldt (Site 4), known to be relatively clean. During 1987-89, the programme was extended to include 6 additional sites: 2 in

Table 1. Location and characteristics of the sampling sites

\begin{tabular}{|c|c|c|c|c|c|}
\hline \multicolumn{2}{|c|}{ Site } & \multirow{2}{*}{$\begin{array}{l}\text { Habitat } \\
\text { Estuarine }\end{array}$} & \multirow{2}{*}{$\begin{array}{l}\text { Main pollution inputs } \\
\text { River Scheldt }\end{array}$} & \multirow{2}{*}{$\begin{array}{r}\text { Salinity } \\
\left(9 \mathrm{~kg}^{-1}\right)\end{array}$} & \multirow{2}{*}{$\frac{\begin{array}{c}\text { Fishing } \\
\text { depth }(\mathrm{m})\end{array}}{1-5}$} \\
\hline 1 & $\begin{array}{l}\text { Western Scheldt } \\
\text { (Saeftinge) }\end{array}$ & & & & \\
\hline 2 & $\begin{array}{l}\text { Western Scheldt } \\
\text { (Vlissingen) }\end{array}$ & Estuarine & $\begin{array}{l}\text { River Scheldt and the canal } \\
\text { from Gent to Terneuzen }\end{array}$ & $20.5-29.6$ & $1-5$ \\
\hline 3 & $\begin{array}{l}\text { North Sea coast } \\
\text { (Voordelta) }\end{array}$ & Coastal & $\begin{array}{l}\text { Indirectly via River Scheldt, Belgian } \\
\text { coastal waters and Eastern Scheldt }\end{array}$ & $29.8-32.0$ & $7-14$ \\
\hline 4 & $\begin{array}{l}\text { Eastern Scheldt } \\
\text { (Hammen) }\end{array}$ & $\begin{array}{l}\text { Estuarine, } \\
\text { semi-enclosed }\end{array}$ & $\begin{array}{l}\text { Only indirectly from Hollands Diep via } \\
\text { Volkerak and River Scheldt; relatively clean }\end{array}$ & $29.3-30.8$ & $1-5$ \\
\hline 5 & $\begin{array}{l}\text { North Sea coast } \\
\text { (Hook of Holland) }\end{array}$ & Coastal & $\begin{array}{l}\text { Water from the Rhine and } \\
\text { Meuse }\end{array}$ & $26.9-28.8$ & $7-14$ \\
\hline 6 & $\begin{array}{l}\text { North Sea coast } \\
\text { (IJmuiden) }\end{array}$ & Coastal & $\begin{array}{l}\text { Directly from North Sea Canali } \\
\text { indirectly via water from Rhine }\end{array}$ & $27.7-29.2$ & $14-21$ \\
\hline 7 & $\begin{array}{l}\text { North Sea coast } \\
\text { (Callantsoog) }\end{array}$ & Coastal & $\begin{array}{l}\text { No direct discharges indirectly } \\
\text { via Sites } 5 \text { and } 6\end{array}$ & $28.9-30.4$ & $7-21$ \\
\hline 8 & Wadden Sea & Tidal basin & Lake IJssel and North Sea coastal waters & $28.1-30.1$ & $1-22$ \\
\hline 9 & Ems-Dollard & Estuarine & River Ems & $8.3-14.1$ & $1-5$ \\
\hline $\mathrm{S}$ & Offishore spawning area & Open sea & No direct discharges & 31 & $23-36$ \\
\hline
\end{tabular}


coastal waters (Sites 3 and 7), 1 in the Wadden Sea (Site 8), and a further 3 sites in 2 different estuaries, the Western Scheldt (Sites 1 and 2) and the Ems-Dollard (Site 9) (Fig. 1).

Sampling of the spawning population in late winter (February-April): In 1988 and 1989 sampling was conducted over a large offshore area which included flounder spawning grounds (Area S). At the time of sampling this population consists mainly of flounder which have migrated from Dutch coastal waters (De Veen 1971)

The characteristics of each site and the main sources of pollution are shown in Table 1 .

Sampling procedure. Fishing operation: Most fishing was carried out by the 2 research vessels RV 'Octans' (1983-6j) dnd RV' 'Sndil Agi' (19985-89̂). The gear used was a $6 \mathrm{~m}$ beam trawl fitted with 2 to 4 tickler chains, and a 'sole net' having a $7 \mathrm{~cm}$ mesh in the main net and a cod-end mesh of $4 \mathrm{~cm}$.

At each site a number of tows were made within a delimited area (Fig. 1) until the desired sample size was attained. The depth fished at each site was recorded (Table 1). Each tow lasted between 35 and $80 \mathrm{~min}$, and at each site a minimum of 4 tows were made, but the number was usually greater and varied depending on the size of the catch. Additional samples were taken by local shrimp trawlers or by gill nets at Sites 1, 2 and 9, where for technical reasons fishing with the $6 \mathrm{~m}$ beam trawl was not possible.

Data obtained using different vessels or fishing methods were combined for analysis, since prevalences did not vary significantly with these factors (Vethaak 1993).

Stratified sampling: Only flounder with a total length of $20 \mathrm{~cm}$ or more were examined, smaller individuals being virtually absent from coastal sites at the time of sampling. Fish were divided into 3 length classes: $20-24.9,25-29.9$ and $\geq 30 \mathrm{~cm}$. The objective was to collect at least 150 fish in each length class at each site. This sample size would allow major spatial and temporal differences to be reliably detected. Also, a total sample of 450 fish per site allows the detection of a disease having a prevalence of at least $1.0 \%$ with a probability of $95 \%$ (Thursfield 1986).

Although the target sample size for the middle length class $(25-29.9 \mathrm{~cm})$ was usually reached at all sites, some difficulty was experienced in collecting enough large fish ( $\geq 30 \mathrm{~cm}$ ) at Site 9 , and more often in collecting enough small fish $(20-24.9 \mathrm{~cm})$ at some coastal sites, especially Sites 3 and 6 . Therefore, data for the small and middle length classes were pooled in the statistical analyses.

Inspection for disease. Inspection for disease signs concentrated on 3 major conditions, as follows:

(1) Lymphocystis (Fig. 2a-d). This viral disease can be recognised by the presence of nodules, usually creamy-white in colour, but occasionally pigmented, on the skin covering the body and/or fins. Sometimes nodules are found in the gill or oral cavity. When at least 1 nodule was found on the body or fins, the specimen was recorded as infected by this disease. Where the diagnosis was doubtful, cases were verified by histological examination

(2) Skin ulcers (Fig. 2e, f). These are usually circular open lesions surrounded by a whitish border, but, when in the process of healing, the periphery develops a darker pigment. Healed ulcers can be identified as areas of dark pigment with irregular implantation of scales, but fish with these were not recorded as diseased fish. Only fish with lesions larger than $2 \mathrm{~mm}$ in diameter were recorded as being affected.

(3) Liver neoplasms (Fig. 2g, h). Nodular lesions with well-defined margins and a diameter of $2 \mathrm{~mm}$ or more, situated on the surface of the liver, were included in this category. Frequently these nodules are lighter or darker in colour than the rest of the liver. All nodules were subjected to further histopathological investigation, and only when these were histologically confirmed as neoplasms were the cases retained for statistical analysis (see also Vethaak \& Wester 1996).

Recording of gross lesions, visible to the naked eye, permitted epizootiological investigation of large numbers of fish. Because of time and cost constraints, it would not have been possible to attain such large sample sizes using histological verification in all cases. A total of 18343 individuals captured during 1983-89 were inspected externally for the presence of lymphocystis and skin ulcers. All 14526 individuals captured during 1985-89 were also inspected internally for liver nodules (see Table 2). Every fish was inspected exterally by a combination of visual and tactile examination, lasting approximately 30 to $60 \mathrm{~s}$ per fish. On each occasion, fish were examined by a small group of workers in close cooperation, and there was a large degree of continuity from year to year. The comparability of different prevalence estimates is dependent on the degree of agreement among different examiners. In these studies, agreement was close to $100 \%$ (Vethaak 1993).

Age determination. During 1987 and 1988, otoliths were taken from a random subsample of 10 healthy individuals per cm length group at each site, and also from all diseased fish. After the fish had been aged, length-age keys were determined separately for healthy and diseased fish at each site according to the method of Van Leeuwen \& Vethaak (1988).

Using the length-age keys, and the individually determined ages of the diseased fish, the 1987 and 1988 samples were reclassified into 3 age categories $(2,3$, and $4+y r$ old fish) for additional statistical analysis. 
Other potential risk factors. Condition factor: A gutted condition factor $[\mathrm{C}=100 \times$ somatic weight $(\mathrm{mg}) \times$ total length $\left.(\mathrm{mm})^{-3}\right]$ was determined for a sub-sample of at least 40 female fish (length $20-29.9 \mathrm{~cm}$ ) at each site every year. These fish were stored on ice after removal of the viscera and later weighed in the laboratory.

Salinity: For each site the observed range of salinities (Table 1 ) is based on mean values derived from a routine monitoring programme carried out by RWS during 1983-89.

Fishing activity: An index of total fishing activity at each sampling location was calculated as the total boat-days spent within each area by beam trawlers and shrimp boats in 1987 (Netherlands Institute for Fishery Research, RIVO-DLO, unpubl. data). Year-toyear variation in fishing activity for the study area as a whole was estimated from available data for the same types of boats, expressed as horsepower (hp) days (Smit 1990).

Contaminant concentrations in livers: Concentrations of polychlorinated biphenyls (PCBs), and the heavy metals cadmium ( $\mathrm{Cd}$ ) and lead $(\mathrm{Pb})$ were measured in 2 pooled samples of 20 male and 20 female livers (length $20-29.9 \mathrm{~cm}$ ) collected at each site in 1987 during the fish disease survey. PCB concentrations were determined using hot soxhlet extraction, florisil and silica clean-up, followed by dual column and high resolution gas chromatography. Lipid content was determined by hot soxhlet extraction with hexane/ acetone (3:1). Metal concentrations were determined by graphite furnace atomic absorption spectrometry, after digestion with nitric acid in a pressure bomb. Details of the analytical methods are given in Stronkhorst (1992). Concentrations of PCBs were expressed as the sum of 6 congeners (CB-52, CB-101, CB-118, CB-138, CB-153, and CB-180). As an alternative measure, the concentration of CB-153 alone was also used: this congener showed a high correlation with the other congeners measured and normally constitutes about $10 \%$ of the total PCB burden.

Contaminant concentrations in sediment: Concentrations of PCBs, PAHs [benz(b)fluoranthene, benz(k)fluoranthene, and benz(a)pyrene], and $\mathrm{Cd}$ and $\mathrm{Pb}$ were measured in the $<63 \mu \mathrm{m}$ fraction of superficial sediments from each site. Most sites (Sites 2,4-9) were sampled once in November 1986 or in summer 1987. All sites were sampled once in 1990 or 1991, during September, October or November (data from monitoring surveys of RWS). Analysis of contaminant concentrations was carried out according to standard methods described by the Joint Monitoring Group of ICES (Akkerman et al. 1992). Additional data for Sites 1 and 3 in 1986 were obtained from Anon. (1988). Because of the wide variation of the organic content of sediments from site to site $(2.0$ to $7.5 \%)$, the concentrations of contaminants known to be attached principally to organic matter were expressed relative to organic content.

Data processing and statistical methods. The data were analyzed using a log-linear model with disease accurrence as the dependent variable and site, year. length (or age), and sex as independent variables. The only exception was the analysis of seasonal effects where season was introduced as an independent variable and site effects ignored. The logit model used predicts the log odds (logits) for the dependent variable as an additive function of the other variables. If, in a population exposed to a certain risk factor, the number of fish which have a disease is $A$, and the number not having the disease is $B$, then the prevalence is $A / A+B$, but the odds are $A / B$. This measure of association is commonly used in retrospective epidemiological studies and seems equally suitable for the analysis of data collected from fish disease surveys (Rhodes et al. 1987, Vethaak et al. 1992).

The method allows the estimation of the odds ratio as a linear function of explanatory factors such as site, sampling occasion, length, age or sex. The odds ratio, estimated from the parameter coefficients of the logit analysis, is defined as:

$$
\frac{A / B}{C / D}
$$

where $A$ and $B$ are defined as above, and $C$ and $D$ are the numbers with and without disease in a population not exposed to the risk factor $(C / D$ being the odds for this population). In the present study, where risk factors are not formally defined, the population represented by $C$ and $D$ is selected as follows. Odds ratios for site were expressed relative to Site 4 (reference site), for year relative to the first year of sampling (1983 or 1985), for length and age relative to the small $(20-29.9 \mathrm{~cm})$ or youngest (age 2) group, and for males relative to females.

Where the confidence intervals of the odds ratio exclude the value of 1 , there exists a significant difference between sites (or years, length groups, sexes, etc.) at the $5 \%$ level. Odds ratios significantly greater than 1 indicate an increased probability of disease, and odds ratios significantly less than 1 a decreased probability. The parameters were estimated using the statistical package GLIM (Baker \& Nelder 1978), assuming a binomial error structure. Since the numbers of fish analyzed for each combination of independent factors varied, the design is unbalanced and therefore each main effect was tested by comparing 2 models, one with all the main effects included and the other with that particular main effect excluded. Interaction effects were tested by comparing the model with all 

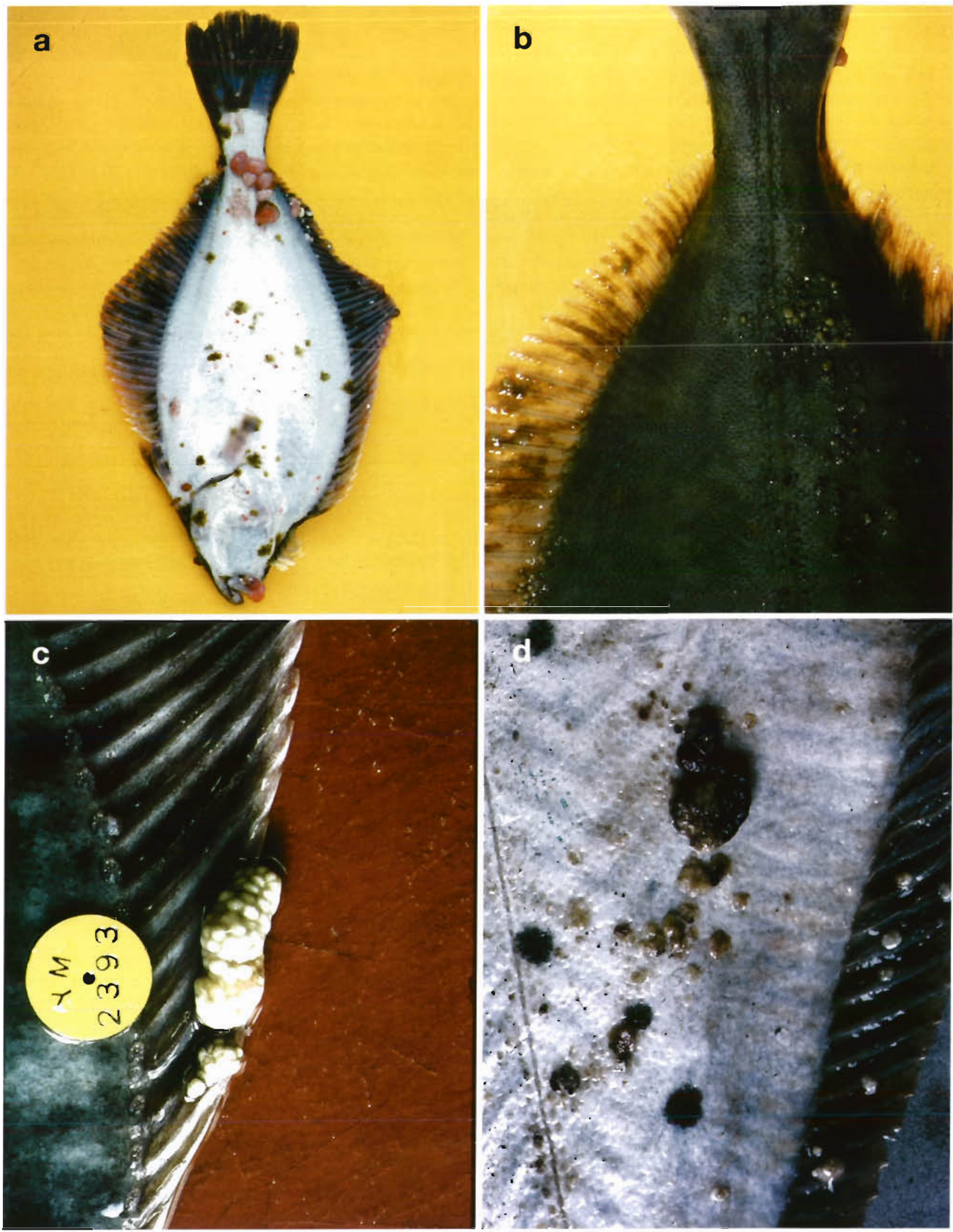

Fig. 2. Platichthys flesus. Appearance of 3 visible diseases in flounder from Dutch waters. (a) Specimen severely affected with lymphocystis nodules and pseudotumours (underside). (b) Lymphocystis nodules and pseudotumours on body and fin (upper side). (c) Clusters of typical lymphocystis nodules giving a tumour-like appearance on fin (upper side). (d) Specimen with lymphocystis nodules (underside) 


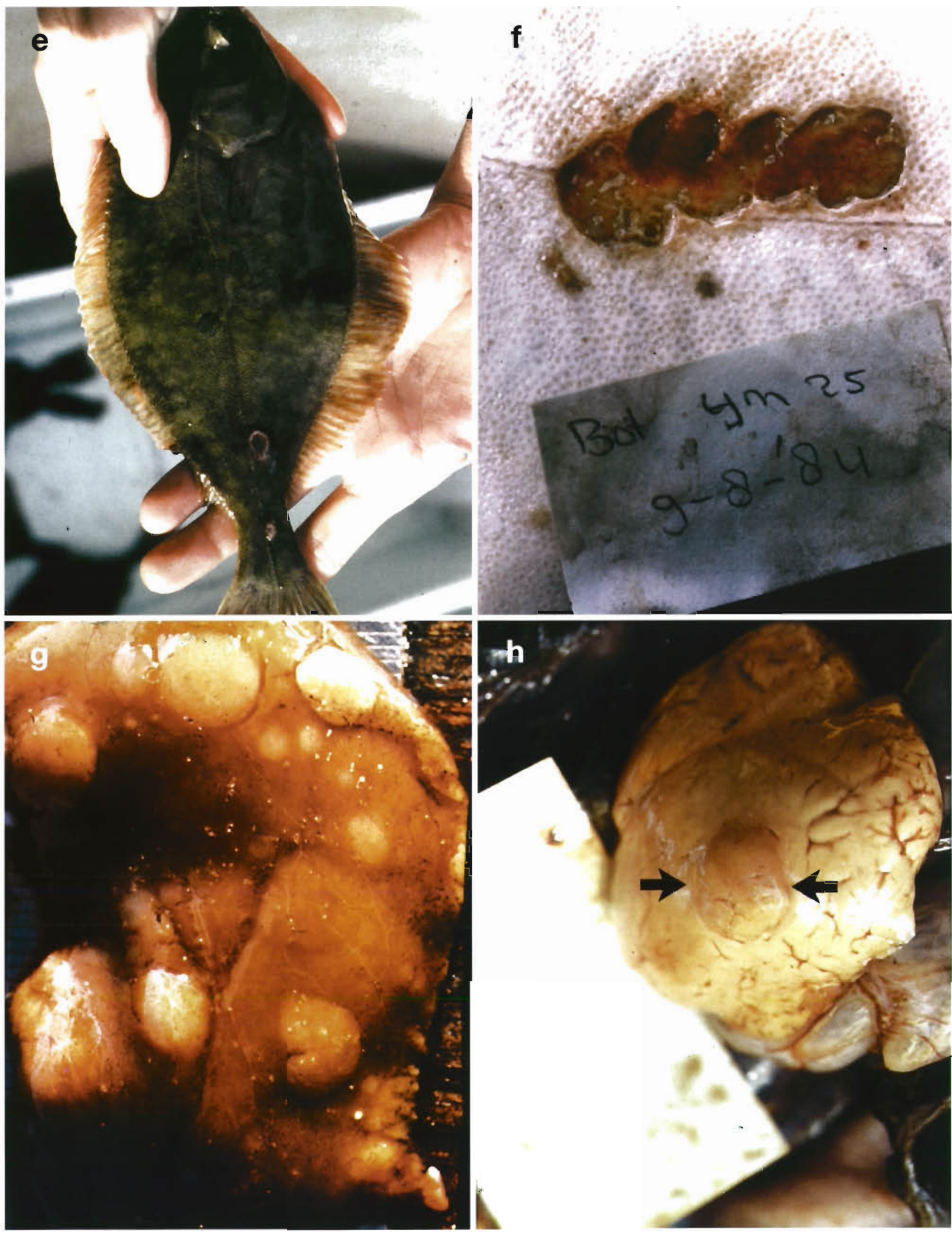

(e) Specimen affected with skin ulcers (upperside). (f) Close-up of overlapping skin ulcers (underside). (g) Liver affected with multiple nodules. (h) Liver showing 1 large nodule 
main effects and the interaction effect under consideration to the model with the main effects only. Because the statistical analysis involved numerous tests ( $>50$; the limit according to the Bonferroni inequality), the level of significance for each test separately was kept low $(\alpha=0.01)$, in order to ensure a low experiment-wise error rate.

The following data sets were analyzed separately:

(1) For spatial trends, September data on all 3 diseases for $1987-89$;

(2) For year-to-year variation, September data on lymphocystis and skin ulcers for 1983-89 and data on liver neoplasms for $1985-89$ at 3 sites;

(3) For effects of season, data on all 3 diseases for 1988-89, site effects being ignored;

(4) For efiects of age, September data on all 3 diseases for 1987-88.

Disease odds for each site were calculated using parameter coefficients derived from the model fitted to Data Set 1 (see above). Similarly, the disease odds for each year were calculated using the model fitted to Data Set 2. Then, simple regression was used to test correlations between (log) disease odds and other potential risk factors such as salinity, fishing activity, and contaminant exposure. To establish correlations between disease occurrence and liver contaminant concentrations, estimated disease odds for each site in 1987 were used, matching the chemical data; concentrations of contaminants in males and females were pooled. Only where a significant effect of sex on disease occurrence was found, were data from male and female fish analyzed separately.

Patterns of co-occurrence of different diseases in individual flounder were determined by using a chisquared test of independence with the critical chivalue set at $p=0.05$

\section{RESULTS}

\section{Crude disease prevalences}

In Table 2 observed disease prevalences in late winter and late summer (irrespective of size, sex, and year) are presented for each site. It can be seen that lymphocystis was the predominant disease with an overall prevalence of $14.3 \%$, followed by skin ulcers with $2.8 \%$. The overall prevalence of liver neoplasms was $1.0 \%$.

\section{Effects of length, sex, site, year and season}

Spatial patterns: 1987-89 data set (late summer only)

Lymphocystis. The log-linear analysis showed that there were significant differences among sites, years, length groups and sexes. However, there were no significant 2 -way interactions and thus the model finally chosen included only these 4 main effects.

Relative to the reference site, all other sites showed significantly higher estimated odds for lymphocystis. Odds ratios increased along the coastal transect going from Site 3 to Site 7 . The odds ratio for flounder from the Wadden Sea (Site 8) was comparable to that at Site 3, while odds at the estuarine sites (Sites 1,2 and 9) were lower, though still higher than at the reference site. Large flounder were more likely to have lymphocystis than small ones, and males more likely than females (Table 3).

Skin ulcers. For skin ulcers, only site and year were significant main effects, indicating that length and sex did not affect the occurrence of the disease. Again, 2 -way interactions were not significant.

Table 2. Platichthys flesus. Observed prevalences of lymphocystis (\%LYM), skin ulcers (\%ULC) and liver neoplasms (\%LNP) at each site (all sizes and years combined) in late summer (September) and in late winter (February-April). $N=$ no. of fish examined

\begin{tabular}{|c|c|c|c|c|c|c|c|c|}
\hline \multirow[t]{2}{*}{ Season } & \multirow[t]{2}{*}{ Site } & \multicolumn{4}{|c|}{ External diseases } & \multicolumn{3}{|c|}{ Liver neoplasms } \\
\hline & & Years & $N$ & $\%$ LYM & $\%$ ULC & Years & $N^{2}$ & $\%$ LNP \\
\hline \multirow[t]{10}{*}{ Late summer } & 1 & $1987-89$ & 1160 & 7.2 & 1.0 & $1987-89$ & 1160 & 0.0 \\
\hline & 2 & $1987-89$ & 1368 & 7.2 & 1.1 & $1987-89$ & 1368 & 0.1 \\
\hline & 3 & $1987-89$ & 818 & 16.1 & 2.4 & $1987-89$ & 818 & 1.3 \\
\hline & 4 & $1983-89$ & 3423 & 4.4 & 1.4 & $1985-89$ & 2363 & 0.1 \\
\hline & 5 & $1983-89$ & 3885 & 20.0 & 3.4 & $1985-89$ & 2385 & 0.8 \\
\hline & 6 & $1983-89$ & 2693 & 22.8 & 3.9 & $1985-89$ & 1436 & 1.9 \\
\hline & 7 & $1987-89$ & 1269 & 24.1 & 4.7 & $1987-89$ & 1269 & 3.4 \\
\hline & 8 & $1987-89$ & 1054 & 12.0 & 1.5 & $1987-89$ & 1054 & 0.3 \\
\hline & 9 & $1987-89$ & 817 & 4.3 & 2.0 & $1987-89$ & 817 & 0.0 \\
\hline & Total & $1983-89$ & 16487 & 14.1 & 2.6 & $1985-89$ & 12670 & 0.8 \\
\hline Late winter & $\mathrm{S}$ & $1988-89$ & 1856 & 16.5 & 4.6 & $1988-89$ & 1856 & 1.8 \\
\hline All sites + seasons & $1-9+S$ & $1983-89$ & 18343 & 14.3 & 2.8 & $1985-89$ & 14526 & 1.0 \\
\hline
\end{tabular}


Table 3. Platichthys flesus. Estimated odds ratios (with $95 \%$ confidence intervals) for effects of site, length and sex on the occurrence of lymphocystis (LYM), skin ulcers (ULC), and liver neoplasms (LNP), adjusted in each case for the effects of year and other variables. Effects of sex were not included in the analysis of liver neoplasms

\begin{tabular}{|c|c|c|c|c|}
\hline Effect & Relative to & LYM & ULC & LNP \\
\hline Site 1 & Site 4 & $2.0(1.4-2.9)$ & $0.5(0.3-1.1)$ & $0.0(0.0-0.0)$ \\
\hline Site 2 & Site 4 & $2.4(1.7-3.3)$ & $0.6(0.3-1.1)$ & $0.6(0.1-6.2)$ \\
\hline Site 3 & Site 4 & $3.8(2.6-5.1)$ & $1.3(0.7-2.3)$ & $6.8(1.5-31.1)$ \\
\hline Site 5 & Site 4 & $4.0(2.3-5.5)$ & $1.8(1.1-3.0)$ & $6.3(1.4-28.4)$ \\
\hline Site 6 & Site 4 & $4.5(3.1-6.6)$ & $2.0(1.1-3.7)$ & $19.5(4.4-87.0)$ \\
\hline Site 7 & Site 4 & $6.0(4.4-8.1)$ & $2.7(1.7-4.2)$ & $15.7(3.7-65.9)$ \\
\hline Site 8 & Site 4 & $3.8(2.7-5.3)$ & $0.9(0.5-1.6)$ & $2.3(0.4-14.2)$ \\
\hline Site 9 & Site 4 & $1.8(1.2-2.8)$ & $0.2(0.1-0.4)$ & $0.0(0.0-0.0)$ \\
\hline Large & Small & $3.2(2.7-3.7)$ & - & $10.1(4.8-21.2)$ \\
\hline Male & Female & $2.1(1.9-2.5)$ & - & - \\
\hline
\end{tabular}

Estimated odds ratios were significantly greater than 1 at the coastal sites (Sites 3, 5, 6 and 7) but not at the Wadden Sea site (Site 8). The estimated odds ratios for Sites 6 and 7 were particularly high (Table 3). Large flounder were more likely to have neoplastic liver nodules than small ones (Table 3).

Although the effect of sex on the prevalence of liver neoplasms was ignored, a comparison of the crude data indicated that older female flounder more frequently had liver nodules than males, by a factor of about 2 (Fig. 3).
Relative to the reference site, only 4 sites had significantly higher or lower estimated odds. At 3 coastal sites (Sites 5, 6 and 7) the odds for skin ulcers were higher than at Site 4, whereas in the Ems-Dollard estuary (Site 9) they were lower (Table 3).

Liver neoplasms. For liver neoplasms, no good fit could be achieved with any model when all 4 explanatory variables (site, year, length, sex) were used. This was due largely to low prevalences and the presence of zero values in many cells of the table. In order to avoid this problem, data from both sexes were pooled. A reasonably good fit was then obtained by the model having all 3 main effects but no 2 -way interactions.

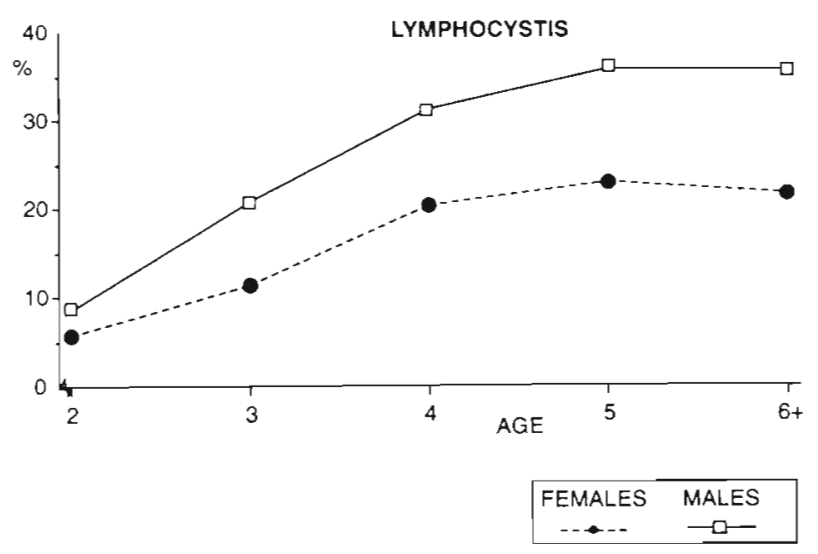

Fig. 3. Platichthys flesus. Age-specific observed prevalences of lymphocystis, skin ulcers and liver neoplasms in male and female flounder in 1987-88 (data from all sites pooled)
Year-to-year variation: $1983-89$ or 1985-89 data set (late summer only)

Significant main effects of some or all of the variables site, year, length and sex were found, depending on the disease. No significant 2-way interaction effects between these 4 variables were detected. Models finally chosen were similar to those obtained by analysing the spatial data set.

Table 4 presents estimated odds ratios for different years, length groups and sexes, derived from the models finally chosen. For lymphocystis, odds were significantly higher in 1984-88 (relative to 1983), and peaked in 1986 . However, the odds for the disease in
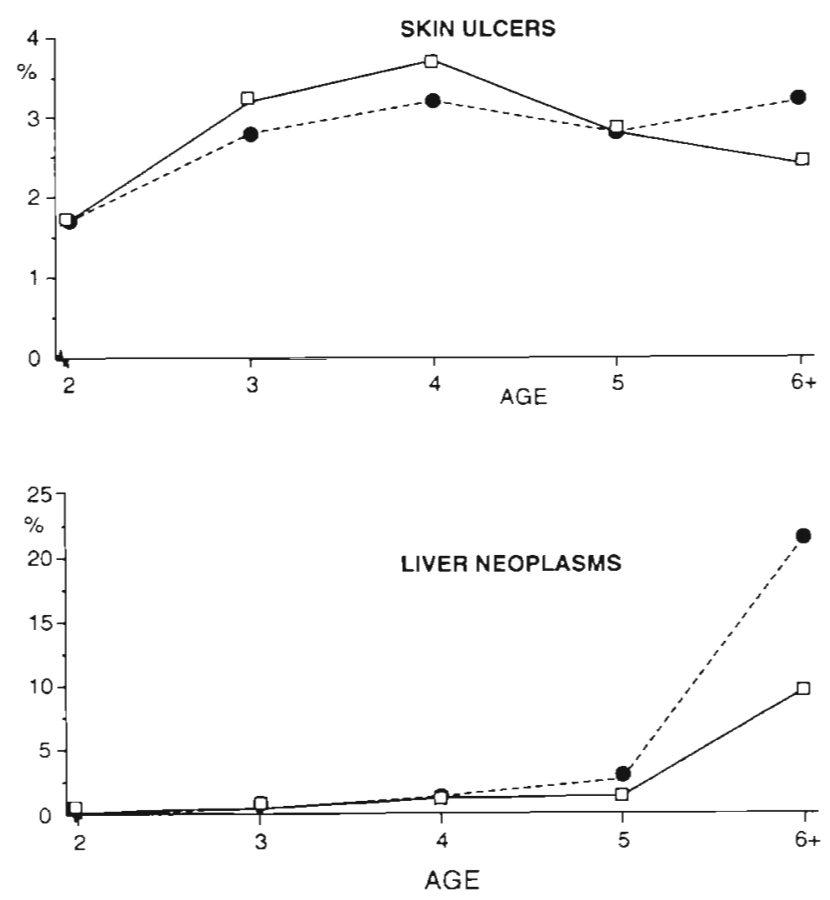
Table 4. Platichthys flesus. Estimated odds ratios (with $95 \%$ confidence intervals) for effects of year, length and sex on the occurrence of lymphocystis (LYM), skin ulcers (ULC), and liver neoplasms (LNP), adjusted in each case for the effects of site and other variables. Ettects of sex were not included in the analysis of liver neoplasms. Note that for liver neoplasms the effect of year is expressed relative to 1985

\begin{tabular}{|c|c|c|c|c|}
\hline Effect & Relative to & LYM & ULC & LNP \\
\hline 1984 & 1983 & $1.9(1.5-2.4)$ & $2.3(1.5-3.6)$ & - \\
\hline 1985 & 1983 & $1.8(1.4-2.4)$ & $2.0(1.2-3.3)$ & - \\
\hline 1986 & 1983 (1985) & $2.6(2.0-3.2)$ & $1.1(0.6-1.9)$ & $1.0(0.4-2.5)$ \\
\hline 1987 & 1983 (1985) & $1.5(1.2-2.0)$ & $1.1(0.6-2.1)$ & $4.3(1.7-1.1 .0)$ \\
\hline 1988 & 1983 (1985) & $1.8(1.3-2.3)$ & $2.4(1.4-4.0)$ & $1.7(0.6-4.7)$ \\
\hline 1989 & $1983(1985)$ & $0.8(0.6-1.2)$ & $2.1(1.2-3.6)$ & $1.2(0.4-3.5)$ \\
\hline Large & Small & $3.3(2.9-3.8)$ & - & $4.9(2.1-11.1)$ \\
\hline Male & Female & $2.4(2.1-2.7)$ & - & - \\
\hline
\end{tabular}

\section{Age as an explanatory variable}

\section{Length-age relationships}

Growth rates of flounder appeared to be considerably higher at the estuarine sites (Sites 1, 2,4 and 9) than at the coastal sites (Sites 3, 5, 6 and 7). For example, fish in the middle length class $(25-29.9 \mathrm{~cm})$ averaged $2.0 \mathrm{yr}$ of age at Site 9 , but 2.9 yr of age at Site 5 , even though the mean lengths were similar. There appeared to be no difference in length-age relationships between healthy fish and those with lymphocystis or skin ulcers. However,

1989 were not significantly different from those in 1983. Estimated odds ratios for large fish and male fish (Table 4) approximate to values obtained by analysing the spatial data (Table 3 ).

For skin ulcers, the odds ratios showed considerable temporal variation, peaking in 1984 and 1988. However, 1986 and 1987 are not statistically different from 1983 (Table 4). Odds ratios for liver neoplasms showed a peak in 1987, being 4.3 times higher than in 1985. As expected, large fish were much more likely to have liver neoplasms than small fish, the odds ratio being 4.9 (Table 4).

\section{Seasonal variation: $1988-89$ data set}

In the case of lymphocystis, the best-fitting log-linear model included the main effects length, sex, and a significant interaction between season and year. The existence of the interaction indicated a significantly higher prevalence in late winter 1989 as compared to late summer 1989, but no such difference in 1988. The prevalence of lymphocystis increased with length and was higher in males than females.

For skin ulcers, the model finally chosen included length (but not sex) and again a significant interaction between year and season. The pattern of seasonal variation was similar to that shown by lymphocystis. Again, prevalences increased with fish length.

The model giving the best fit for the data on liver neoplasms included significant effects of length, sex and season. In this case, there was no significant year effect and no significant interaction. In both years prevalences of liver neoplasms were significantly higher in late winter than in late summer, the estimated odds ratio being $2.5195 \%$ confidence limits 1.6-4.1). As in the previous analysis, prevalences of liver neoplasms increased with fish length and were higher in females than in males. indications were found that flounder with liver neoplasms showed slower growth rates than apparently healthy ones, thus justifying the use of separate lengthage keys for diseased and healthy fish in this case (author's unpubi. results)

Spatial patterns: $1987-88$ data set (September only)

Results of the log-linear analysis gave broadly similar results to the analysis based on length, with all main effects significant in the case of lymphocystis and liver neoplasms. Similarly, the estimated odds ratios did not seem to alter the patterns obtained previously, although estimates were less precise, particularly in the case of skin ulcers and liver neoplasms for which prevalences were relatively low. Because effects of year were ignored, the effects of sex on the occurrence of liver neoplasms could be included in this analysis, with the estimated odds ratio being $0.4( \pm 95 \%$ confidence intervals $0.2-0.6$ ) for males relative to females.

An examination of the age composition of fish at each site (Fig. 4) shows trends which are not apparent from the statistical analysis. Particularly noticeable is the lack of old fish at some estuarine sites (Sites 1, 2 and 9), particularly at Site 9 where only 2 and 3 yr old fish were caught.

With age, the prevalence of lymphocystis showed a steady increase in both males and females until they were about 5 yr old, and then levelled off (Fig. 3). In contrast, the prevalence of skin ulcers, although increasing up to the age of $4 \mathrm{yr}$, decreased in older fish (Fig 2). This latter trend was not detected by the loglinear analysis.

Age-specific prevalences for liver neoplasms (Fig. 3) showed a steep increase in $6 \mathrm{yr}$ old fish. The scarcity or absence of liver nodules from some sites may be explained in terms of the age structure of the population. At Site 9, for example, the sample was composed 


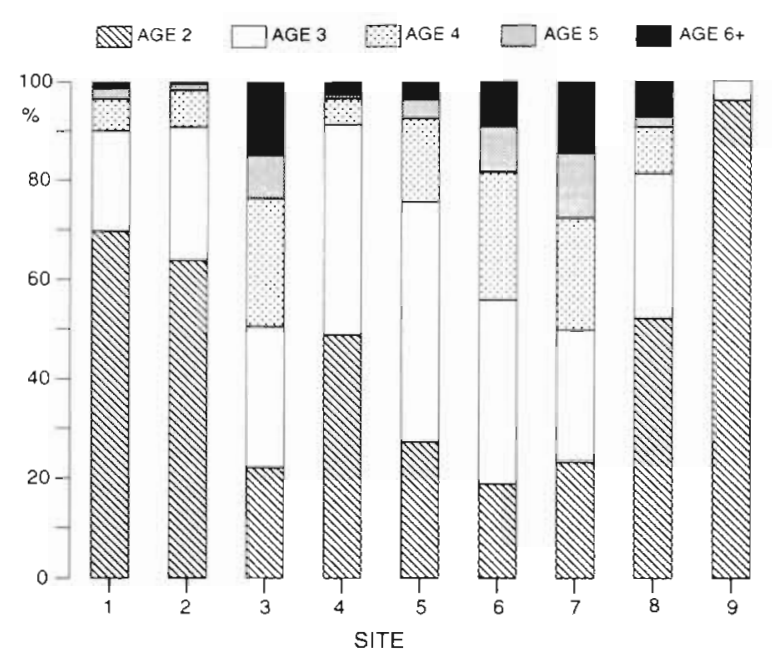

Fig. 4. Platichthys flesus. Age composition of flounder sampled at each site (data for both sexes pooled)

almost exclusively of 2 yr old fish (Fig. 4). On the other hand, $3.2 \%$ of the 1562 and 3 yr old fish examined at Site 6 had liver neoplasms, whereas none of the much larger number of similarly aged fish from Sites 1 and 2 were affected.

\section{Associations among disease conditions}

Skin ulcers were found in $3.6 \%$ of the fish affected by lymphocystis, whereas the corresponding percentage was only $2.3 \%$ in fish unaffected by lymphocystis. The association was highly significant $(p=0.004)$. This is in agreement with the overlap in their spatial patterns. Liver neoplasms, on the other hand, were not significantly associated with either lymphocystis or skin ulcers $(p=0.06$ and 0.84 respectively).

\section{Relationships with other potential risk factors}

\section{Condition factor}

Mean condition factors in September varied between 0.92 and 1.16 according to site and year. There was considerable year-to-year variation within the study area. At Sites 4, 5 and 6, temporal differences over 7 yr were largely consistent with a maximum in 1987, falling to low values in 1988 and 1989. This fall to low values towards the end of the study was also detectable at most other sites (data for only 3 yr). No clear spatial trend emerged.

The overall condition factor of flounder during the spawning period was 0.82 in 1988 and 0.84 in 1989. These values were significantly lower than those at any of the 9 sites in September of the same years.

\section{Salinity}

A significant correlation was found between the occurrence of liver neoplasms and mean salinity at each site $(\mathrm{r}=+0.75 ; \mathrm{p}=0.01$, but this was not the case for lymphocystis $(r=+0.38 ; p=0.22)$ and skin ulcers $(\mathrm{r}=+0.53 ; \mathrm{p}=0.13)$. It should be noted, however, that the distribution of sites was heavily biased towards high salinity values with only Sites 1,2 and 9 having medium or low salinities. It is clear from the data that these low-salinity sites were associated with low prevalences of lymphocystis and skin ulcers (Table 2).

\section{Fishing activity}

Fig. 5a indicates the relative intensity of fishing at each site in 1987. The pattern in 1988 and 1989 was considered to be similar (RIVO-DLO unpubl. data). Fig. 5b shows year-to-year variation in relative fishing activity.

Spatial variation in fishing intensity was found to be significantly positively correlated with the occurrence of lymphocystis ( $\mathrm{r}=+0.67, \mathrm{p}=0.05)$, skin ulcers $(\mathrm{r}=+0.80, \mathrm{p}<0.01)$ and liver neoplasms $(\mathrm{r}=+0.83$.
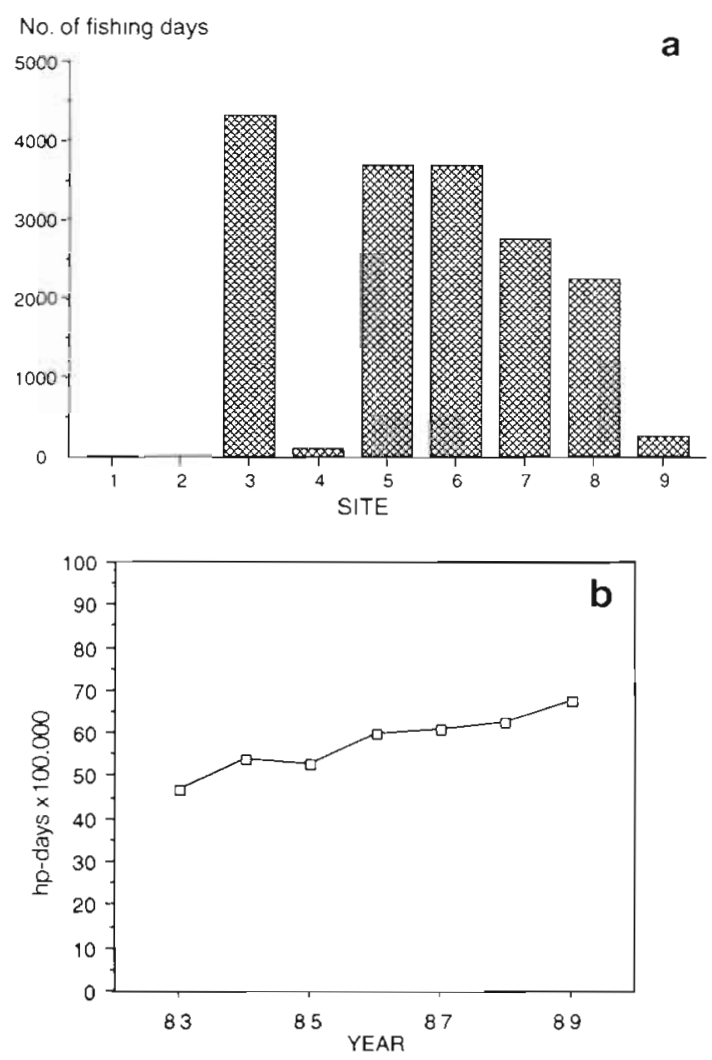

Fig. 5. (a) Total number of fishing days fished by commercial vessels at each sampling site in 1987. (b) Number of horsepower (hp) days $(\times 100000)$ fished by commercial vessels $<300 \mathrm{hp}$ for various years 
$p<0.01$ ). By contrast, year-to-year variation in fishing activity was not significantly correlated with yearto-year variation in disease prevalences $(p>0,60)$.

\section{Contaminant concentrations}

Concentrations of PCBs in livers were similar in males and females, with the exception of Site 2 where females showed concentrations almost twice as high as males (Fig. 6). Concentrations were higher at Sites 2, 3 and 5 than at the other sites, which appeared to differ little among themselves (Fig. 6). The high values at Site 2 , and perhaps also at Site 3 , probably indicate a local source of pollution originating from the Western Scheldt, whereas Site 5 is affected by discharges from the Rhine. Again, concentrations of $\mathrm{Cd}$ in the liver were similar in males and females, but concentrations were highest at Sites 1 and 2; the other sites differed little among themselves (Fig. 6). Concentrations of $\mathrm{Pb}$ were all below the limit of detection.

The spatial patterns of all 4 groups of contaminants in sediments were rather similar in 1986-87 and 1990-91, but concentrations of Cd were notably higher at Site 1 on the earlier occasion and at Site 6 on the latter occasion (Fig. 7).
Table 5. Platichthys flesus. Correlation coefficients between adjusted (log) disease odds for lymphocystis (LYM), skin ulcers (ULC), and liver neoplasms (LNP) and mean concentrations of indicator contaminants in (a) liver and (b) sediment for all sites (plain text) and for the 6 marine sites only (italic text). $" p<0.05, \cdots p<0.01$. Data in (a) refer to small flounder $(20-29.9 \mathrm{~cm}$ in length) sampled in September 1987. Data in (b] refer to flounder sampled in 1987-89 during September

\begin{tabular}{|c|c|c|c|c|}
\hline \multicolumn{2}{|l|}{ (a) } & \multicolumn{2}{|c|}{$\begin{array}{l}\text { PCB-153 } \\
\text { Liver }\end{array}$} & $\begin{array}{c}\mathrm{Cd} \\
\text { liver }\end{array}$ \\
\hline \multicolumn{2}{|c|}{ LYM (male) } & \multicolumn{2}{|c|}{$\begin{array}{l}-0.29 \\
-0.14\end{array}$} & $\begin{array}{l}-0.39 \\
-0.22\end{array}$ \\
\hline \multicolumn{2}{|c|}{ LYM (female) } & \multicolumn{2}{|c|}{$\begin{array}{l}-0.11 \\
-0.06\end{array}$} & $\begin{array}{l}-0.39 \\
-0.42\end{array}$ \\
\hline \multicolumn{2}{|c|}{ ULC (both sexes) } & \multicolumn{2}{|c|}{$\begin{array}{r}-0.21 \\
0.37\end{array}$} & $\begin{array}{l}+0.01 \\
-0.61\end{array}$ \\
\hline \multicolumn{2}{|c|}{ LNP (both sexes) } & \multicolumn{2}{|c|}{$\begin{array}{l}-0.12 \\
-0.14\end{array}$} & $\begin{array}{l}-0.15 \\
-0.53\end{array}$ \\
\hline (b) & $\begin{array}{l}\text { PCB-153 } \\
\text { sediment }\end{array}$ & $\begin{array}{c}3 \mathrm{PAH} \\
\text { sediment }\end{array}$ & $\begin{array}{c}\mathrm{Cd} \\
\text { sediment }\end{array}$ & $\begin{array}{c}\mathrm{Pb} \\
\text { sediment }\end{array}$ \\
\hline LYM & $\begin{array}{l}-0.19 \\
+0.13\end{array}$ & $\begin{array}{l}-0.26 \\
-0.02\end{array}$ & $\begin{array}{l}+0.37 \\
+0.09\end{array}$ & $\begin{array}{l}+0.56 \\
+0.58\end{array}$ \\
\hline ULC & $\begin{array}{l}-0.34 \\
+0.62\end{array}$ & $\begin{array}{l}-0.47 \\
+0.48\end{array}$ & $\begin{array}{l}+0.26 \\
+0.71\end{array}$ & $\begin{array}{l}+0.46 \\
+0.94^{\circ}\end{array}$ \\
\hline LNP & $\begin{array}{l}+0.44 \\
-0.35\end{array}$ & $\begin{array}{l}-0.58 \\
+0.44\end{array}$ & $\begin{array}{l}+0.16 \\
+0.77\end{array}$ & $\begin{array}{l}+0.37 \\
+0.82\end{array}$ \\
\hline
\end{tabular}

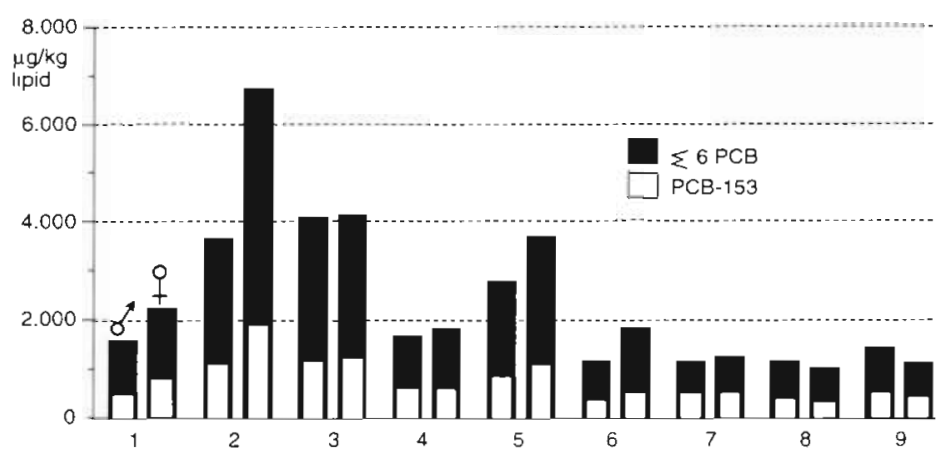

No significant correlations were detected between the concentrations of the different contaminants in liver and the occurrence of lymphocystis, skin ulcers and liver neoplasms (Table 5a). In the case of lymphocystis, these correlations were tested for males and females separately, because of the significant effect of sex on the occurrence of the disease. This picture did not change when the analysis was restricted to the 6 marine sites in order to eliminate a possible bias due to salinity (Table 5a).

Also, no significant correlations were de-

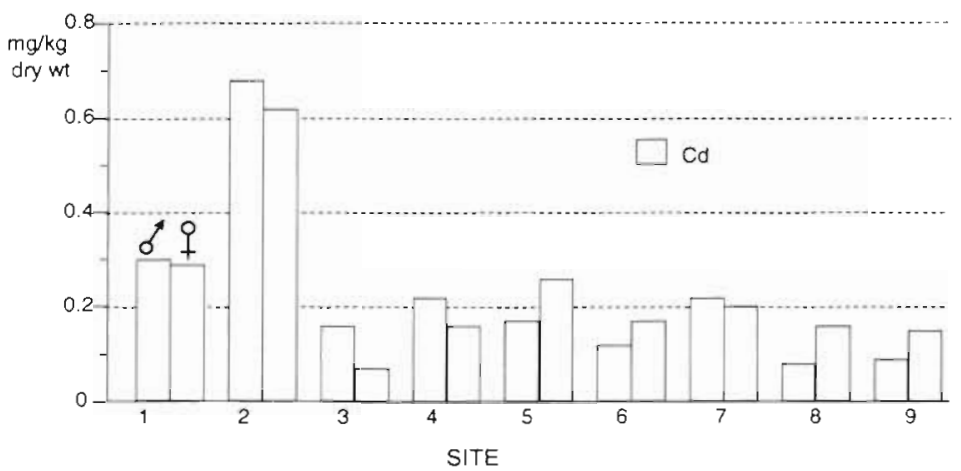

Fig. 6. Platichthys flesus. Mean concentrations of PCB and $\mathrm{Cd}$ in the livers of male and female flounder $20-29.9 \mathrm{~cm}$ in length at each sampling site in September 1987. For PCBs, concentrations of an individual congener (PCB-153) and of the sum of 6 congeners (CB-52, CB-101, CB$118, \mathrm{CB}-138, \mathrm{CB}-153$, and $\mathrm{CB}-180$ l are given different contaminants in sediment and the occurrence of lymphocystis, skin ulcers and liver neoplasms (Table 5b). When the analysis was restricted to the 6 marine sites, $\mathrm{Pb}$ in sediment showed positive correlations with the occurrence of skin ulcers and liver neoplasms (Table 5b).

Concentrations of PCBs in the sediments, although significantly positively correlated with each of the 3 other contaminant groups $(p<0.01$; not shown in Table 5$)$, showed no apparent correlation with PCB concentrations in the liver of the fish ( $p=0.98)$ This discrepancy is partly due to low concentrations in the liver at Site 1. 

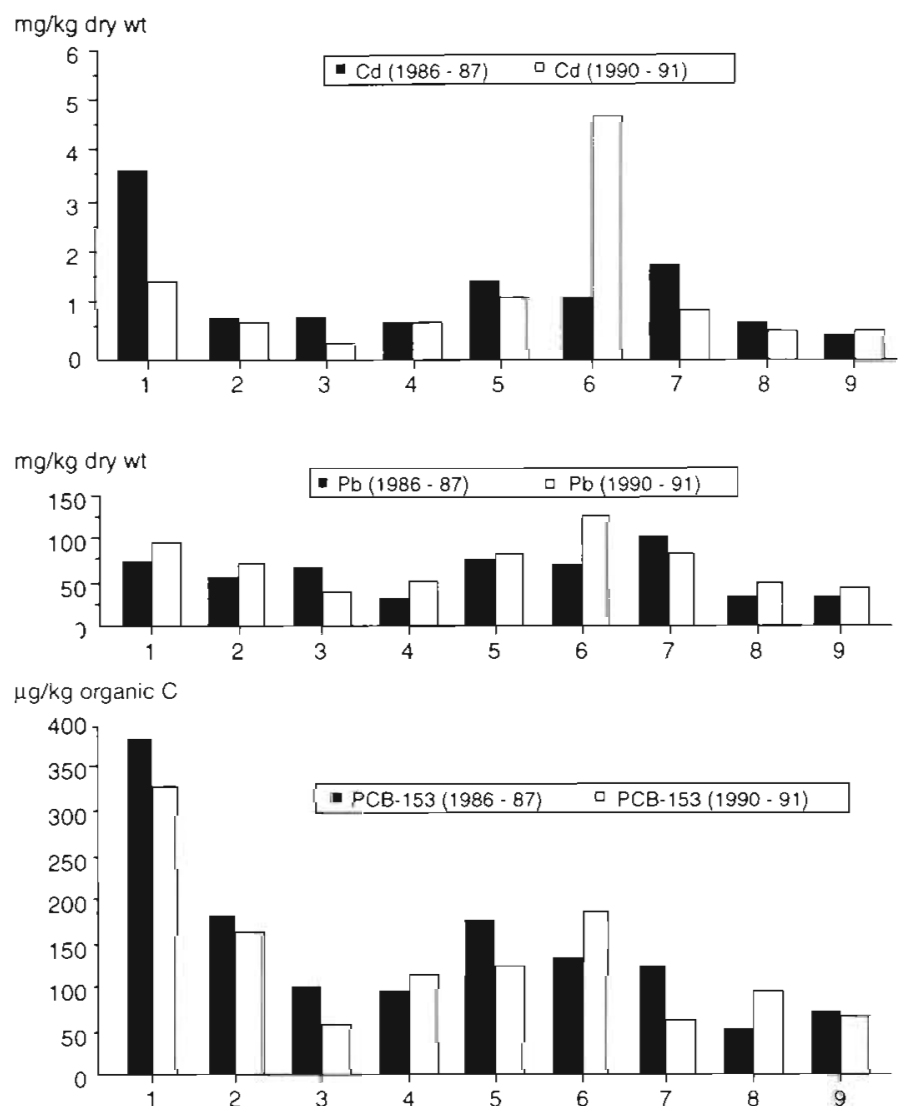

$\mu \mathrm{g} / \mathrm{kg}$ organic C

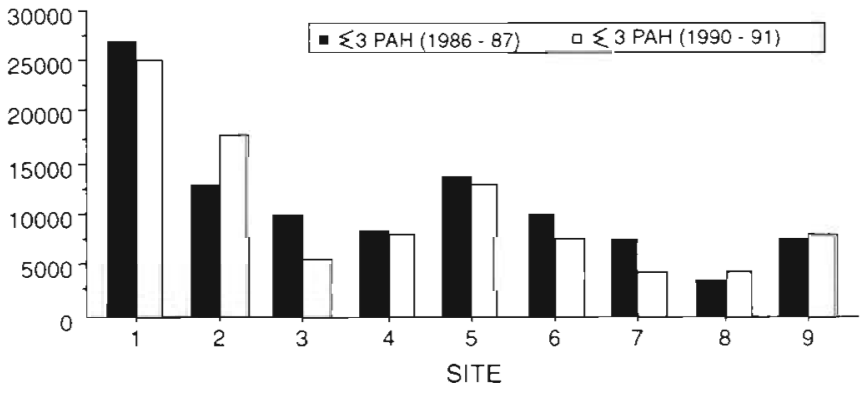

Fig. 7. Mean concentrations of $\mathrm{Cd}, \mathrm{Pb}, \mathrm{PCB}-153$, and the sum of 3 PAH [benz(b)fluoranthene, benz(k)fluoranthene + benz(a)pyrene] in the $<63 \mu \mathrm{m}$ fraction of sediments at each site in $1986 / 87$ and 1990/91

\section{DISCUSSION}

The results reveal considerable similarities in the spatial distribution of the 3 diseases studied. Despite their different aetiologies, this suggests that a common causal mechanism may contribute to their development, particularly as 2 of the diseases (lymphocystis and skin ulcers) were associated in individual fish as well. Year-to-year variation and the relationship with age and sex, however, showed little similarity among the different diseases.
Nevertheless, the results show for the sites with high salinities (Sites 3 to 8 ; Table 1) that, with the exception of skin ulcers at Site 8 , prevalences of all the diseases were considerably lower at the Eastern Scheldt reference site (Site 4) than at the other sites (Tables $2 \& 3$ ). This would appear to justify the choice of Site 4 as a reference site.

The finding that salinity could be an important factor affecting skin diseases of flounder is in agreement with earlier studies on the same species in the Elbe (Moller 1990) and the Dutch Wadden Sea (Vethaak 1992). Also, the absence of liver neoplasms in fish from waters of low salinity agrees with the findings of Peters et al. (1987) in the heavily polluted Elbe estuary. However, considering the strong association shown between fish age and risk of neoplasm occurrence in the present study, this finding may be partly influenced by the much lower proportion of 4 to $6 \mathrm{yr}$ old fish $(<10 \%)$ sampled at the lower salinity sites (Sites 1,2 and 9) relative to the higher-salinity coastal sites.

The nature of the reduced disease risk associated with low salinity remains uncertain. The occurrence, activity or pathogenicity of the lymphocystis virus or of bacteria associated with skin ulcers might show a positive relationship with salinity, but the same is unlikely to apply to liver neoplasms. Other factors may therefore be involved, such as spawning and associated migration. In general, spawning fish are subjected to stresses including poor nutritional status and a high population density (Rijnsdorp \& Vethaak 1989) which may lower their resistance to infection, offering an explanation for the observed seasonal increase in prevalences of lymphocystis and skin ulcers. For neoplasms, the annual variation in food intake with consequent changes in the amounts of glycogen and lipid stored in the liver may be involved. In the present study, this variation was apparent from measurements of a quantitative index of hepatic storage of glycogen and/or lipid (Vethaak \& Wester 1996). It is possible that this process occurring in the liver is linked to an increased turnover of hepatocytes, for example, thereby promoting tumour formation.

In principle, a low condition factor caused by malnutrition might increase disease risk, as proposed by Möller (1990) for flounder in the Elbe. This factor was also considered important for flounder populations near drainage sluices in the Wadden Sea (Vethaak 1992). However, the present analysis indicates that malnutrition is unlikely to play an important role in the development of disease during summer. Although 
estuarine sites were included in the present study, they are not comparable to those studied by Vethaak (1992) in terms of salinity fluctuations, population density, and other factors. Prevalences of skin ulcers were considerably lower in the present study.

The apparent seasonal decrease in prevalences between late winter and late summer raises the question of what happens to the affected fish during the intervening period. Lesions may undergo a process of regression and disappear, as in the case of skin ulcers where scars as well as intermediate healing stages were frequently observed. A similar explanation might also apply to the reversible precursor stages of liver neoplasms, but another possibility is that fish bearing these lesions are rapidly eliminated from the population as a result of increased mortality.

Flounder have a low commercial value in The Netherlands and they are generally discarded from catches. In the coastal zone there are intensive flatfish and shrimp fisheries, and fresh or healed wounds which can be ascribed to damage by fishing gear are commonly observed in flounder from these areas. It seems not unlikely that damage to the protective mucous layer of the skin could make fish more vulnerable to infectious pathogens. In general, the sites characterized by the most intensive fishing activity (Sites 3, 5 and 6) showed highest disease prevalences, and the reference site (Site 4) was unique among the coastal sites in having almost no trawling activity (Fig. 5a). However, it is unlikely that differences in fishing activity can explain the observed yearto-year variation in disease prevalence. For example, the peak of lymphocystis in 1986 did not coincide with any substantial increase of fishing during that year (Fig. 5b). Moreover, the prevalence of skin ulcers was particularly low during the same year. Furthermore, it is difficult to imagine how fishing activity could influence the development of liver neoplasms

Although temperature fluctuations and temperature extremes may interfere with the immune system of fish and affect the occurrence and virulence of pathogens (Zeeman \& Brindley 1981), differences among the various sites in the present study were small $\left(2\right.$ to $4{ }^{\circ} \mathrm{C}$ at most) and seem unlikely to have affected disease prevalences

It is possible that the diet of the flounder may have influenced patterns of disease prevalence. At some sites in 1989, fish were feeding almost exclusively on crustaceans or on bivalves, whereas at others they had mixed diets with a high proportion of polychaetes (Haver 1990).

Although there was some indication of a relationship between contaminant concentrations and spatial patterns of disease for the marine sites alone (Table 5b), the evidence is weak and unconvincing. The present study included relatively few chemical data points and was therefore somewhat limited as far as analyzing the relationships between disease prevalence and contaminant exposure is concerned. Nonetheless, the spatial patterns of heavy metals and organic contaminants observed in this study are in general agreement with those found in routine chemical monitoring programmes involving flatfish and blue mussel Mytilus edulis (Akkerman et al. 1992) during the period of the study. Common features include high concentrations in the Western Scheldt (Sites 1 and 2), and lower levels in the North Sea and Wadden Sea except at the outflow of the river Rhine (Site 5) and the North Sea Canal (Site 6). The pattern is also consistent with the results of Ariese et al. (1993), who measured concentrations of $1-\mathrm{OH}$ pyrene as an indicator of exposure to PAHs in the bile of flounder and other flatfish species in Dutch estuaries and coastal waters in 1991 and 1992. Very high concentrations were found in flounder from the North Sea Canal (mean value: $1900 \mathrm{ng} \mathrm{ml}^{-1}$ bile; $\mathrm{n}=20$ ), whereas intermediate levels were found in the Western Scheldt (mean value: $580 \mathrm{ng} \mathrm{m}^{-1}$ bile; $\mathrm{n}=21$ ) and Ems-Dollard estuaries (mean value: $290 \mathrm{ng} \mathrm{ml}^{-1}$ bile; $\mathrm{n}=7$ ). Concentrations in the coastal North Sea were relatively low (mean values $<130 \mathrm{ng} \mathrm{ml}^{-1}$ bile),

A statistical analysis of PCB-138 and Cd in the liver tissue and of $\mathrm{Hg}$ in the muscle tissue of flounder from Sites 2 and 9 was carried out by Stronkhorst (1992). Only for Cd at Site 9 was there any significant increase in concentrations from 1985 to 1990. These results do not explain the observed year-to-year variation of disease prevalences at these sites.

Since lymphocystis and skin ulcers are infectious diseases, any effect of pollution can only be indirect, for example through immunosuppression or through the activation or increased virulence of a pathogen. By contrast, liver neoplasms might have a direct chemical aetiology without the involvement of infectious agents. Although this has not been established for flounder in particular, chemical contaminants in livers of other fish species are thought to act as carcinogens (Sindermann et al. 1980, Mix 1986, Malins et al. 1988, Hinton 1989, Harshbarger \& Clark 1990, Vethaak \& ap Rheinallt 1992, Myers et al. 1994). The high prevalences of liver neoplasms observed at some coastal sites in the present study thus merit closer examination. Spatial variation in the prevalence of this disease was large but very consistent from year to year. As stated above, differences in the intensity of fishery activity are unlikely to offer a satisfactory explanation for this spatial pattern. However, as discussed above, the fact that the disease was absent from fresh and brackish waters irrespective of pollution status suggests that factors related to low salinity are implicated. These might include agerelated migration and the high abundance of younger fish in populations from these areas. 
For neoplasms as well as the 2 skin diseases, prevalences increased with length and age of the fish. The increase in prevalence with length was approximately linear for both lymphocystis and skin ulcers, but cases of liver neoplasms were concentrated in the largest size category. Since growth is asymptotic, this suggests that the occurrence of neoplasms is related to age rather than length. Indeed, neoplastic nodules were found mainly in individuals older than 6 yr Although the fact that these older age classes were absent from most estuarine sites due to age-related migration might explain the low prevalences, neoplasms were observed in younger flounder ( 2 and 3 yr old) at Sites 5, 6 and 7 , suggesting high exposure to causal agents. A more detailed recent survey of Site 6 , near the outlet of the highly industrialized North Sea Canal, revealed that highest prevalences of liver nodules occurred in young flounder (20-24 cm; age 2) (Van Gennep \& Verboom 1991), suggesting the existence of disease-linked mortality. Extreme exposure to PAHs in the North Sea Canal as found by Ariese et al. (1993) may explain the unusually high prevalence of liver nodules in young flounder in that area.

Apart from having a different aetiology, liver neoplasms also differ from the other 2 diseases studied in having a much longer development period. For a chronic disease, long-term movements and migratory patterns of the host are likely to be important in explaining spatial variation. Large fish at some of the coastal sites may have been exposed to pollution under estuarine conditions at an earlier stage in their lives. For example, flounder at Sites 6 and 7 probably grew up in the North Sea Canal, those at Site 5 in the Rhine, and those at Site 3 in the Western or Eastern Scheldt. Liver neoplasms found in flounder sampled along the North Sea coast, especially at Sites 5 and 6, may be related to recent exposure in the coastal zone, but given the high $1-\mathrm{OH}$ pyrene levels determined in flounder from the North Sea Canal (Ariese et al. 1993), one could argue that PAH uptake in inshore waters at an earlier age might also be an important factor

Knowledge about the exposure of the youngest stages of flounder to pollutants is lacking, but it should be recognized that the initiation of carcinogenesis in fish may involve exposure during the youngest and most sensitive stages (Hinton 1989).

The observed sex-related disease risks for lymphocystis and liver neoplasms may be related to the spawning cycle. Male flounder remain on the offshore spawning grounds for considerably longer periods than females (Rijnsdorp \& Vethaak 1989). The high prevalence of lymphocystis in male flounder relative to females may therefore be explained in terms of stress associated with spawning Conversely, the higher risk of developing liver neoplasms in female fish may also be linked to reproduction. For example, steroid compounds are possible tumour promoters in mammals (Schulte-Herman et al. 1981). Emmerson \& Emmerson (1976) have shown that $17 \beta$-estradiol can cause liver hyperplasia and hypertrophy during vitellogenesis in flatfish, and Nunez et al. (1989) have clearly shown the promoting effects of $17 \beta$-estradiol on liver neoplasia in rainbow trout. It is also possible that differential susceptibility of the 2 sexes to tumour initiation may manifest itself as early as the egg, larval or juvenile stages (Hinton 1989), but information is lacking at present. An alternative but perhaps less satisfactory explanation is differential exposure of the 2 sexes. Since males remain for longer periods than females in the less polluted offshore spawning areas, they may suffer less exposure to pollution, but the extent and significance of this difference has not been established. A similar sex-related difference in the prevalence of liver neoplasms was found in dab (Vethaak \& van der Meer 1991), but does not appear to have been reported elsewhere in the literature.

Certain differences are apparent between the results reported here and published American studies of liver neoplasia in flatfish (Mix 1986, Malins et al. 1988, Myers et al. 1991. 1994, Vogelbein et al. 1990). In the present study, neoplasms appeared to be present in fish from less polluted sites as well as in those from heavily polluted sites, whereas in American waters the disease was restricted to polluted areas. However, it should be stressed that background prevalences of liver neoplasms in flounder from genuinely 'clean' sites are unknown. In the North Sea, any individual flounder may have spent time in a polluted area at some stage during its life, and migratory patterns need further clarification before genuine reference populations can be identified.

\section{CONCLUSIONS}

The present study demonstrates that disease occurrence is influenced by host-related factors such as length, age and sex. Although these biological variables can be accounted and adjusted for in certain types of statistical analysis, the structure and incompleteness of our data sets did not permit simultaneous consideration of these factors in examining the potential influence of pollutant exposure on disease prevalence. Moreover, pollution effects could not be analyzed separately from other envirommental and anthropogenic factors such as salinity and fishing activity. The last 2 factors are positively correlated in the data from the present study, because fishing activity is greatest in coastal waters where salinity is highest. Thus it is not possible to separate out their 
effects, or indeed to consider the effect of pollution acting in isolation. Nevertheless, it is quite clear that in certain estuaries, the negative effects of low salinity and/or absence of fishing on disease prevalence seem to coincide with a population structure dominated by younger fish, which would further mask or counteract the potential effects of contaminant exposure on disease prevalence, especially in the case of neoplasms.

Although salinity, fishing activity, and pollution may partly explain the observed spatial patterns of disease. year-to-year variation appears to require a different explanation. Not only did the 3 diseases studied show different patterns of variation, but in addition none of the factors studied appeared to vary over time in the same way as disease prevalence. Migration and other factors associated with spawning seem to play an important role in determining observed seasonal and year-to-year variation in disease prevalence.

The findings of the study do not indicate a clear and universal relationship between pollution and disease prevalence, but suggest instead that disease causation is complex. Effects of salinity, fishing activity, migration and spawning behaviour may interact with those of pollution to produce observed spatial patterns. Of the diseases studied, the evidence for a relationship with pollution is perhaps strongest for liver neoplasms.

Acknowledgements. We are indebted to the Netherlands Institute for Fishery Research (RIVO-DLO), under whose supervision most of this work was carried out. We are especially grateful to Drs Paul van Banning, Paul Hagel and Niels Daan for their cooperation and advice. For assistance during field work, we are grateful to the crews of the research vessels RV 'Smal Agt', RV 'Octans', and RV 'Schollevaar', and the fishing vessels 'YM25' and 'TH5'. In all, help with this work was provided by over a hundred people. It would be impossible to name them all, but we are particularly indebted to Balt Verboom (RIVO-DLO) for his contribution. Diagnosis of histological sections was carried out in conjunction with Dr Peter Wester of the Laboratory of Pathology, National Institute of Public Health and Environmental Protection. Financial support was provided by the North Sea Directorate of the Public Works Department (Rijkswaterstaat). Two anonymous reviewers provided useful comments which considerably improved the manuscript.

\section{LITERATURE CITED}

Akkerman I, Kersten H, Valk F, van der Deinum G (1992) National evaluation report of the Joint Monitoring Programme of the Netherlands 1990 including national comments of the Netherlands 1990. Tidal Waters Division Rep DCiW-92.003, Ministry of Transport, Public Works and Water Management, Rijkswaterstaat, The Hague

Anon (1988) Contaminanten in sedimenten van de Westerschelde (Contaminants in sediments of the Western Scheldt). Report T62, Delft Hydraulics Laboratory, Delft

Ariese F, Vethaak AD, Hofstraat JW, Gooijer C, Velthorst NH (1993) Synchronous fluorescence spectrometry of fish bile: field studies at the southern North Sea and in Dutch coastal and inshore waters. In: Ariese F (ed) Shpol'skII spectroscopy and synchronous fluorescence spectroscopy: bromonitoring of polycyclic aromatic hydrocarbons and their metabolites, Section 6.2. Doctorate thesis, Free University of Amsterdam, p 143-163

Baker RJ, Nelder JA. (1978) The GiLM System. Release 3: generalized linear interactive modelling. Numerical Algorithms Group, Oxford

Bucke D, Feist SW, Rolfe M (1983a) Fish disease studies in Liverpool Bay and the north-east Irish Sea. ICES CM/E:5

Bucke D, Norton M, Rolfe MS (1983b) The field assessment of effects of dumping wastes at sea. II. Epidermal lesions and abnormalities of fish in the outer Thames Estuary. Tech Rep No. 72, MAFF Direct Fish Res, Lowestoft

Bucke D, Watermann B, Feist S (1984) Histological variations of hepato-splenic organs from the North Sea dab, Limanda limanda L. J Fish Dis 7:255-68

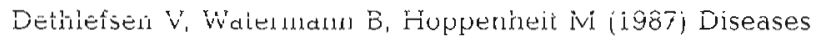
of North Sea dab (Limanda limanda L.) in relation to biological and chemical parameters. Arch FischWiss 37: $107-237$

De Veen JF (1971) Bot, een sportieve vis (The flounder, a sporting fish). Visserij 24:189-197 (in Dutch)

Ehrenbaum E (1908) Versuche mit gezeichneten Flundern oder Elbbutt (Pleuronectes flesus) (Experiments with marked flounder). Wiss Meeresunt Abt Helgoland 8:203-219 (in German)

Emmerson BK, Emmerson J (1976) Protein, RNA and DNA metabolism in relation to ovarian vitellogenic growth in the flounder Platichthys flesus. Comp Biochem Physiol 55(B):315-321

Harshbarger JC, Clark JB (1990) Epizootiology of neoplasms in bony tish of North America. Sci Tot Environ 94:1-32

Haver T (1990) De samenstelling van het voedsel van de bot (Platichthys flesus) in de Nederlandse wateren (Composition of the diet of flounder in Dutch coastal waters). Int Rep GWAO-90.025, Nat Inst for Coastal and Marine Management/RIKZ, The Hague, (in Dutch)

Hinton DE (1989) Environmental contamination and cancer in fish. Mar Environ Res 28:411-416

Köhler A (1989) Regeneration of contaminant-induced liver lesions in flounder-experimental studies towards the identification of cause-effect relationships. Aquat Toxicol $14: 203-232$

Malins DC. McCain BB, Landahl JT, Myers MS, Krahn MM, Brown DW, Chan SL, Roubal WT (1988) Neoplastic and other diseases in fish in relation to toxic chemicals: an overview. Aquat Toxicol 11:43-67

Marquenie JM, Vethaak AD (1989) Effecten van verontreinigingen in zoutwater ecosystemen (Effects of pollutants in marine ecosystems). In: Stortelder PMB, Kooper WF (eds) Effecten van verontreinigde waterbodems op aquatısche ecosystemen. Vereniging voor Milieuwetenschappen, Vught, p 91-103 (in Dutch with English summary)

MCArdle J, Dunne T, Parker M, Martyn C, Rafferty D (1982) A survey of diseases of marine flatfish from the east coast of Ireland in 1981. ICES-CM/E:47

Mix MC (1986) Cancerous diseases in aquatic animals and their association with environmental pollutants: a critical literature review. Mar Environ Res 20:1-141

Möller $H$ (1990) Association between diseases of flounder (Platichthys flesus) and environmental conditions in the Elbe estuary, FRG. J Cons Perm Int Explor Mer 46:187-199

Möller H, Anders K (1986) Diseases and parasites of marine fishes. Verlag Möller, Kiel

Moore MJ, Smolowitz R, Stegeman JJ (1989) Cellular altera- 
tions preceding neoplasia in Pseudopleuronectes americanus from Boston Harbor. Mar Environ Res 28:425-429

Myers MS, Landahl JT, Krahn MM, McCain BB (1991) Relationships between hepatic neoplasms and related lesions and exposure to toxic chemicals in marine fish from the U.S. West Coast. Environ Health Perspect 90:7-16

Myers MS, Stehr CS, Olson OP, Johnston LL, McCam BB Chàn SL, Varanasi U (1994) Relationships between toxicopathic hepatic lesions and exposure to chemical contaminants in English sole (Pleuronectes vetulus), starry flounder (Platichthys stellatus), and white croaker (Genyonemus lineatus) from selected marine sites on the Pacific Coast, U.S.A. Environ Health Perspect 102:200-215

Newell PF, Appleton TC, Brown BE, Carnworth JW (1979) Elemental distribution in relation to skin necrosis of marine flatfishes from the English Channel. Mar Biol 51:93-99

North Sea Task Force (1993) Quality status report of the North Sea 1993. Oslo and Paris Commissions, London. Olsen and Olsen, Fredensborg

Nunez O, Hendricks JD, Arbogast DN, Fong AT, Brian CL, Bailey GS (1989) Promotion of aflatoxin B1 hepatocarcinogenesis in rainbow trout by $17 \beta$-estradiol. Aquat Toxicol 15:289-302

Perkins EJ, Gilchrist JRS, Abbott OJ (1972) Incidence of epidermal lesions in fish of the north-east Irish Sea area, 1971. Nature 238:101-103

Peters $N$, Köhler A, Kranz H (1987) Liver pathology in fishes from the lower Elbe as a consequence of pollution. Dis Aquat Org 2:87-97

Redeke HC (1908) Over de voortplanting en het trekken van bot (On the reproduction and migration of flounder). Meded. Visscherij XV: 59-62, 82-87, 97-103, 114-119 (in Dutch)

Reiersen LO, Fugelli K (1984) Annual variation in lymphocystis infection frequency in flounder, Platichthys flesus (L.). J Fish Biol 24:187-191

Rhodes LD, Myers MS, Gronlund WD, McCain BB (1987) Epizootic characteristics of hepatic and renal lesions in English sole, Parophrys vetulus, from Puget Sound. J Fish Biol 31:395-407

Rijnsdorp AD, Vethaak AD (1989) Beschrijving van de populaties van bot (Platichthys flesus (L)) in de Noordzee en het Nederlandse kust- en binnenwater (Description of the populations of flounder in the North Sea and Dutch coastal and inland waters). In: Spec Rep Tidal Waters Division. Ministry of Transport, Public Works and Water Management, Rijkswaterstaat, The Hague (in Dutch)

Schulte-Herman R, Ohde G, Schuppler J, TimmermannTroisiener I (1981) Enhanced proliferation of putative preneoplastic cells in rat liver following treatment with the tumour promotors phenobarbital, hexachloro-cyclohexane, steroid compounds and nafenopin. Cancer Res 41: 2556-2562

Shelton RGJ, Wilson KW (1973) On the occurrence of lymphocystis, with notes on other pathological conditions, in the flatfish stocks of the north-east Irish Sea. Aquaculture $2: 395-410$

Sindermann CJ, Bang FB, Christensen NO, Dethlefsen V, Harshbarger JC, Mitchel JR, Mulcahy MF (1980) The role

Responsible Subject Editor: D. E. Hinton, Davis, California, USA and value of pathobiology in pollution effects monitoring programs. Rapp P-V Réun Cons Perm Int Explor Mer 179: $135-151$

Smit W (1990) Landbouw Economisch Instituut, Visserij in cijfers. Yearly reports 31-83 until 31-89. LEI, The I Iague

Stronkhorst $J$ (1992) Trends in pollutants in blue mussel Mytilus edulis and flounder Platichthys flesus from two Dutch estuaries, 1985-1990. Mar Pollut Bull 24:250-258

Thursfield M (1986) Veterinary epidemiology. Butterworth, London

Van Gennep DRO, Verboom B (1991) Een onderzoek naar het voorkomen van visziekten bij bot (Platichthys flesus) in de buitenhaven in IJmuiden en het Noordzeekanal in 1990 (Fish disease survey in the harbour of IJmuiden and the North Sea Canal in 1990). Contract Rep MO 91-201, Netherlands Institute for Fishery Research (RIVO-DLO), IJmuiden, (in Dutch)

Van Leeuwen P, Vethaak AD (1988) Growth of European flounder (Platichthys flesus) and common dab (Limanda limanda) in Dutch coastal waters with reference to healthy and diseased fish. ICES-CM/G:54

Vethaak AD (1985) Prevalence of fish diseases with reference to pollution of Dutch coastal waters. Rep CA 85-01, Netherlands Institute for Fishery Investigations, IJmuiden

Vethaak AD (1987) Fish diseases, signals for a diseased environment? In: Peet $G$ (ed) Reasons for concern (Proc 2nd North Sea Seminar '86, Vol. 2). Werkgroep Noordzee, Amsterdam, $p$ 41-61

Vethaak AD (1991) On the occurrence of liver tumors in flat fish in Dutch coastal waters. ICES-CM/E:8

Vethaak AD (1992) Diseases of flounder (Platichthys flesus) in the Dutch Wadden Sea and their relation to stress factors. Neth J Sea Res 29:257-272

Vethaak AD (1993) Fish disease and marine pollution-the case of the flounder (Platichthys flesus) in Dutch coastal and estuarine waters. PhD thesis, University of Amsterdam

Vethaak AD, ap Rheinallt T (1992) Fish disease as a monitor of marine pollution: the case of the North Sea. Rev Fish Biol Fish 2:1-32

Vethaak AD, Bucke D, Lang T, Wester P, Jol J, Carr M (1992) Fish disease monitoring along a pollution transect: a case study using dab (Limanda limanda) in the German Bight, North Sea. Mar Ecol Prog Ser 91:173-199

Vethaak AD, van der Meer $\sqrt{ }(1991)$ Fish disease monitoring in the Dutch part of the North Sea in relation to the dumping of waste from titanium dioxide production. Chem Ecol 5: $149-170$

Vethãk AD, Wester PW (1996) Diseases of flounder Platichthys flesus in Dutch coastal and estuarine waters, with particular reference to environmental stress factors. II. Liver histopathology. Dis Aquat Org 26:99-116

Vogelbein WK, Fournie JW, Van Veld PA, Huggett RJ (1990) Hepatic neoplasms in the mummichog Fundulus heteroclitus from a creosote-contaminated site. Cancer Res 50: 5978-5986

Zeeman MG, Brindley WA (1981) Effects of toxic agents upon fish immune systems: a review. In: Sharma RP (ed) Immunologic considerations in toxicology. CRC Press Inc, Boca Raton, FL, p 1-60

Manuscript first received: September 23, 1994 Revised version accepted: January 17, 1996 